\title{
Perilaku Masyarakat Dalam Melaksanakan Gerakan 5 M Pada Pencegahan Penularan Covid-19 di Kota Mataram
}

\author{
Siti Aisyah $^{1 *}$ Irni Dwiastiti Irianto $^{1}$ dan Salia Nurlaela ${ }^{1}$ \\ ${ }^{1}$ Jurusan Ilmu Keperawatan, Universitas Nahdlatul Wathan, Mataram, Indonesia \\ *Email : mutiaraaisyah01@gmail.com
}

\begin{abstract}
Abstak : Awal tahun 2020, dunia digemparkan dengan merebaknya virus yaitu virus corona jenis baru (SARS coV -2) dan penyakitnya disebut corona virus disease 2019 (covid-19) diketahui asal mula virus ini berasal dari Wuhan Tiongkok ditemukan pada akhir desember tahun 2019 sampai saat ini sudah dipastikan terdapat 65 negara yang telah terjangkit virus ini.

Tujuan penelitian ini untuk mengetahui perilaku masyarakat dalam melaksanakan $5 \mathrm{M}$ pada pencegahan penularan covid 19 di kota mataram NTB. Penelitian ini menggunakan teknik deskriptif hanya mengetahui bagaimana perilaku masyarakat dalam melaksanakan gerakan 5M. jumlah sampel adalah 100 orang. Alat pengumpulan data yang di gunakan adalah kuesioner melalui google form.

Hasil penelitian dari perilaku masyarakat didapatkan bahwa responden memiliki kategori patuh yaitu 84 responden $(84 \%)$, dan yang kurang patuh berjumlah 15 responden $(15 \%)$, sedangkan tidak patuh berjumlah 1 responden $(1 \%)$.

Kesimpulan: dari hasil penelitian terhadap perilaku masyarakat dalam melaksanakan gerakan $5 \mathrm{M}$ di kota Mataram Masyarakat lebih banyak patuh.

Diharapkan: Masyarakat lebih patuh dalam melaksanakan gerakan 5M untuk memutus penularan covid-19.
\end{abstract}

Kata Kunci : perilaku, covid 19, gerakan 5M, kepatuhan.

\section{Pendahuluan}

Diawal tahun 2020, dunia digemparkan dengan merebaknya virus baru yaitu corona virus jenis baru (SARS coV 2) dan penyakitnya disebut corona virus disease 2019 (covid 19) diketahui asal mula virus ini berasal dari Wuhan Tiongkok ditemukan pada akhir desember tahun 2019sampai saat ini sudah dipastikan terdapat 65 negara yang telah terjangkit virus satu ini (WHO, Maret 2020). badan kesehatan dunia secara resmi menyatakan virus corona sebagai pendemi Global tak terkecuali di Indonesia semenjak pandemi covid 19 melanda Indonesia banyak daerah daerah yang terkena dampaknya. mendesak (social distancing), dari segi perekonomia mempengaruhi dunia usaha.

Berbagai macam upaya untuk mengantisipasi peyebaran virus covid 19 di Indonesia sudah dilakukan diseluruh daerah diantaranya dengan memberikan kebijakan membatasi aktivitas keluar rumah (Yunus \& Rezki, 2020) aktivitas sosial dilarang dan ditunda sementara waktu, melemahkan ekonomi, pelayanan transportasi dikurangi dan di atur dengan ketat, pemerintah menutup tempat wisata, pusat perbelanjaan, dan tempat hiburan sepi pengunjung, bahkan bekerja dan belajarpun dirumah secara online (Syafrida \& Hartati, 2020).

Berikut permasalahan yang timbul menjadi salah satu saya mengambil penelitian ini yaitu seperti yang kita ketahui keadaan sekarang sedang mengalami covid 19 ini merupakan penyakit yang menular dengan cepat berbagai kebijakan yang dikeluarkan oleh pemerintah terutama penerapan protokol kesehatan diantaranya mencuci tangan, memakai masker, menjaga jarak, mengurangi mobilitas, menghindari kerumunan masyarakat disini sebagai sasarannya dalam penerapannya agar dapat memutus mata rantai penularan covid 19 .

Adapun data kasus di Indonesia 1,61 juta jiwa dengan total sembuh 1,47 juta jiwa serta meninggal dunia 43,7777 Ribu jiwa sedangkan di NTB 1171 ribu jiwa dengan total sembuh 10.690 ribu jiwa serta meninggal dunia 547 jiwa dan yang ada di mataram data kasusnya 3.279 ribu jiwa dengan total sembuh 2,720 ribu jiwa serta meninggal dunia 156 jiwa (JHU CSSE Covid-19 data). Covid 19 tidak hanya berdampak pada segi kesehatan saja melainkan juga segi pendidikan, sosial, perekonomian salah satunya di instusi pendidikan terpaksa meniadakan pembelajaran (dilakukan secara online) dan dari segi sosial mengurangi keluar rumah kalau tidak ada keperluan.

\section{Metode penelitian}

Jenis penelitian yang digunakan adalah deskriptif. Pengumpulan data pada penelitian ini menggunakan kuesioner tertutup berdasarkan skala likert, dimana responden diminta untuk memilih salah satu jawaban yang tersedia yaitu : Selalu (nilai 3), kadang kadang (nilai 2), tidak pernah (nilai 1). 


\section{Hasil dan Pembahasan}

\section{Hasil}

Perilaku Masyarakat Perilaku Masyarakat dalam Melaksanakan gerakan 5M di Kota Mataram NTB

\begin{tabular}{|c|c|c|c|}
\hline No & $\begin{array}{c}\text { Perilaku } \\
\text { Masyarakat }\end{array}$ & Jumlah & Persentase \\
\hline 1 & Patuh & 84 & $84 \%$ \\
\hline 2 & $\begin{array}{l}\text { Kurang } \\
\text { Patuh }\end{array}$ & 15 & $15 \%$ \\
\hline 3 & $\begin{array}{c}\text { Tidak Patuh } \\
\text { Jumlah }\end{array}$ & $\begin{array}{c}1 \\
100\end{array}$ & $\begin{array}{c}1 \% \\
100 \%\end{array}$ \\
\hline
\end{tabular}

Berdasarkan tabel menunjukkan bahwa dari 100 responden, sebanyak 84 responden $(84 \%)$ patuh dan 15 responden kurang patuh (15\%) sedangkan $1(1 \%)$ responden tidak patuh.

\section{Pembahasan}

Hasil penelitian ini menunjukkan bahwa perilaku masyarakat dalam melaksanakan gerakan $5 \mathrm{M}$ adalah $84 \%$ sudah patuh. Faktor yang meningkatkan angka kepatuhan pada perilaku masyarakat tentang gerakan $5 \mathrm{M}$ terhadap penularan covid 19 seperti faktor usia, pendidikan, dan pengetahuan (Amalia Rahmi, 2020).

Pada dasarnya masyarakat kota sebagian masyarakat lebih terdidik dan lebih mudah memperoleh informasi mengenai covid-19, sehingga lebih patuh terhadap protokol kesehatan covid 19, perilaku patuh didukung dengan fasilitas pendidikan dan banyaknya perguruan tinggi di perkotaan, namun tidak menutup kemungkinan masyarakat yang memiliki pendidikan yang rendah juga memiliki pengetahuan terkait covid 19 yang lebih baik, dikarenakan banyaknya media promosi kesehatan yang fokus memberikan pengetahuan kepada masyarakat terkait penyakit covid beserta pencegahan dan pengobatannya, pemerintah juga harus memiliki strategi tepat untuk menyebarkan informasi terkait covid sehingga dapat meningkatkan kesehatan khususnya bagi masyarakat yang dianggap beresiko dan memiliki pengetahuan yang cenderung rendah tentang penyakit ini (Purnamasari, 2020).

Faktor pengetahuan merupakan salah satu hal yang penting diperhatikan dalam rangka penanganan khususnya dalam mencegah transmisi penyebaran dan menekan penyebaran virus (Law, Leung \& Xu, 2020) Pengetahuan yang dimiliki ini akan mempengaruhi seseorang dalam menentukan dan mengambil keputusan terhadap suatu permasalahan (Purnamasari, 2020).

Menurut Aprianti N. \& Rahmiati C. (2021) menemukan bahwa kepatuhan masyarakat terhadap protocol kesehatan covid-19 berada pada kategori patuh $(89,6 \%)$, pengetahuan masyarakat terhadap protocol kesehatan covid-19 dominan pada kategori tinggi $(74,2 \%)$ dan sikap masyarakat terhadap protocol kesehatan covid-19 dominan pada kategori positif $(76.1 \%)$.

Berperilaku penerapan $5 \mathrm{M}$ merupakan langkah pelengkap dari 3M yang sebelumnya sudah merupakan bagian dari upaya penghentian penuralan covid 19 (Kemenkes RI, 2021) kampanye $5 \mathrm{M}$ yaitu memakai masker, mencuci tangan, menjaga jarak, mengurangi mobilitas, menghindari kerumunan merupakan satu paket protokol kesehatan yang sangat diperlukan oleh masyarakat untuk mencegah penularan covid 19.

Berdasarkan data 84 responden tergolong patuh karena adanya masyarakat disekitar lingkungan tempat tinggalnya yang terkena covid19, melihat kondisi tersebut masyarakat menjadi sadar dan ditambah lagi dengan pengetahuan yang didapat masyarakat tentang bahaya covid, cara penularan covid serta cara pencegahannya melalui sosialisasi yang dilakukan oleh pemerintah, media informasi dan komunikasi, maka masyarakat memiliki kesadaran tinggi terhadap kepatuhan dalam melaksanakan protokol kesehatan 5M.

Kemudian responden yang tergolong kurang patuh sebanyak 15 orang karena kurangnya kesadaran responden terhadap pelaksanaan protokol kesehatan jawaban kadang-kadang mendominasi pada data tersebut jika dilihat dari program pemerintah dalam menangani penularan covid-19 seperti penyediaan sarana dan parasarana untuk menunjang pelaksanaan 5M sangat optimal akan tetapi kesadaran masyarakat dalam memanfaatkan sarana yang tersedia masih minim.

Adapun 1 responden tergolong tidak patuh karena mereka selalu mengabaikan protokol kesehatan 5M lingkungan sekitar tempat tinggal dan informasi tentang hoax dilingkungan masyarakat banyak bereda oleh karena itu masyarakat selalu mengabaikan program pemerintah dalam penanganan covid-19 kondisi tersebut didukung oleh tidak adanya masyarakat yang terkena covid-19 di sekitar lingkungannya.

\section{Kesimpulan}

Berdasarkan hasil penelitian terhadap Perilaku Masyarakat Dalam Melaksanakan gerakan 5M Di Kota Mataram NTB dapat diambil bahwa sebanyak 84 responden sedangkan yang kurang patuh sebanyak 15 responden dan yang tidak patuh sebanyak 1 responden.

\section{Daftar Pustaka}

Amalia Rahmi, Ilmi B. \& Rizal A. 2021. Hubungan Pengetahuan Dan Tindakan Masyarakat Terhadap 5m Pada Masa Pandemi Di Kelurahan Kuin Utara Banjarmasin Utara Tahun 2021. http://eprints.uniskabjm.ac.id/7372/1/ARTIKEL\%20AMALIA\% 20RAHMI\%2017070067\%20PDF.pdf 
Aprianti N. \& Rahmiati C. (2021) Faktor-faktor yang mempengaruhi kepatuhan masyarakat terhadap protokol kesehatan covid-19. Jurnal STIKES Vol 11 No. 1 (2021). file:///C:/Users/Master/Downloads/1045-

Research\%20Instrument-4947-1-1020201226\%20(2).pdf

JHU CSSE Covid-19 data. 2021. Visualisasi data covid-19.

https://covid19visual.id/persebaran-kasuscovid-19-di-indonesial

Kemenkes, 2021. Kampanye gerakan 5 M Kemenkes

RI. kemkes.go.id/article/read/2021/02/01/46/5m-dimasa-pandemi-covid-19-diindonesia.html

Kementrian kesehatan RI, 2020 pedoman dan pencegahan pengendalian coronavirus disease

(COVID

19).http://www.padk.kemkes.go.id/article/re ad/2021/02/01/46/5-m-dimasa-pandemicovid-19-di-indonesia.html.diakses 26 maret 2020.

Law, Leung \& Xu, 2020. Severe acute respiratory syndrome (SARS) and coronavirus disease2019 (COVID-19): From causes to preventions in Hong Kong. International journal of infection deseases. https://www.sciencedirect.com/science/articl e/pii/S1201971220301922

Notoatmodjo,P. D. S. (2018). Metogologi penelitian kesehatan (cetakan ke). PTRinea Cipta.

Purnamasari, I., \& Raharyani, A. E. (2020). Tingkat pengetahuan dan perilaku tentang covid-19 jurnal ilmiah kesehatan, mei, 33-42.

Syafrida \& Hartati, 2020). Bersama melawan virus covid-19 di Indonesia. Journal uinjkt. Vol.7 $\begin{array}{lll}\text { No. } & 6 & \text { (2020). }\end{array}$ http://journal.uinjkt.ac.id/index.php/salam/ar ticle/view/15325

Yunus \& Rezky, (2020). Kebijakan Pemberlakuan lock down sebagai antisipasi penyebaran corona virus covid-19. Jurnal syar-I vol. 7 no. 3 (2020). 